\title{
Brown adipose tissue: what have we learned since its recent identification in human adults
}

\author{
Tecido adiposo marrom: o que aprendemos desde \\ sua recente identificação em humanos adultos
}

Bruno Halpern', Marcio Correa Mancini', Alfredo Halpern'

\begin{abstract}
Brown adipose tissue, an essential organ for thermoregulation in small and hibernating mammals due to its mitochondrial uncoupling capacity, was until recently considered to be present in humans only in newborns. The identification of brown adipose tissue in adult humans since the development and use of positron emission tomography marked with 18-fluorodeoxyglucose (PET-FDG) has raised a series of doubts and questions about its real importance in our metabolism. In this review, we will discuss what we have learnt since its identification in humans as well as both new and old concepts, some of which have been marginalized for decades, such as diet-induced thermogenesis. Arq Bras Endocrinol Metab. 2014;58(9):889-99
\end{abstract}

\section{Keywords}

Brown adipose tissue; obesity; thermogenesis; UCP-1; energy expenditure

\section{RESUMO}

O tecido adiposo marrom, órgão essencial para a termorregulação de animais hibernantes e pequenos devido à sua capacidade desacopladora, era até poucos anos considerado presente apenas em recém-nascidos na espécie humana. A identificação do tecido adiposo marrom em adultos com o desenvolvimento e uso da tomografia de emissão de pósitron marcado com 18-fluorodesoxiglicose (PET-FDG) gerou questões sobre sua real importância para nosso metabolismo. Nesta revisão, discutiremos o que aprendemos nesse tempo, assim como conceitos antigos e novos, alguns marginalizados por décadas, como a termogênese induzida por dieta. Arq Bras Endocrinol Metab. 2014;58(9):889-99

\section{Descritores}

Tecido adiposo marrom; obesidade; termogênese; UCP-1; diabetes; PET-FDG
1 Grupo de Obesidade e Síndrome Metabólica, Disciplina de Endocrinologia e Metabologia, Hospital das Clínicas da Faculdade de Medicina da Universidade de São Paulo (HCFMUSP), São Paulo, SP, Brazil

\section{INTRODUCTION}

$\mathrm{T}$ he first description of brown adipose tissue dates from 1551 when Gessner described, in an anatomy book, the tissue as being "nec pinguitudo nec caro", which means "neither fat nor flesh" (1). However, it has only been recognized as a mammal specific thermogenic organ, essential for mammalian thermoregulation, for less than half a century (2). It was believed, for the second half of the $20^{\text {th }}$ Century and the beginning of the $21^{\text {st }}$, to only be present in the human newborn and that it began to involute throughout childhood $(2,3)$. Although some indirect evidence had led a few authors to postulate its presence before $(1,4-9)$, it was only when positron emission tomography marked with 18-fluorodeoxyglucose (PET-FDG), a functional imaging method that evaluates areas of greater metabolic activity, started being used more frequently in the follow-up of some cancers, that brown adipose tissue was identified in at least one subgroup of the adult human population $(2,10-14)$. This amazing discovery was of great interest to medical researchers in the field and to the hypothesis that the presence or absence of brown adipose tissue could be a causal effect in common nontransmissible diseases such as obesity and type 2 diabetes, and could also be a potential therapeutic target since thermogenesis wastes extra energy. 


\section{What is brown adipose tissue?}

Being present uniquely in mammals, as already mentioned, the main function of brown adipose tissue is thermoregulation via non-shivering thermogenesis (1). Thermogenesis occurs due to a unique and specific enzyme, called UCP-1 (Uncoupling Protein-1), which uncouples ATP energy production in the mitochondria, generating heat instead $(1,15)$. UCP-1 is a unique protein that promotes proton leakage across the inner mitochondrial membrane, reducing its transmembrane electrochemical proton gradient, and therefore producing non shivering thermogenesis via heat production $(1,15)$. UCP-1 is a marker of thermogenic adipocytes (not only the classic brown but also the recently discovered beige adipocytes that will later be discussed) and it is believed to be the only protein physiologically capable of inducing non-shivering thermogenesis, as UCP-l knock-out mice can only produce heat by shivering $(2,16,17)$.

Brown adipose tissue is activated by sympathetic noradrenergic stimuli, mainly via $\beta-3$ receptors, although other receptors can activate it too $(2,18)$. Cold is the main physiological stimuli to this noradrenergic activation, as mammals need to maintain their thermoneutrality, but it has long been speculated that it may also be activated by food $(2,17,19)$.

When brown adipose tissue is analyzed by microscopy, cells are seen with multiple fat droplets and multiple mitochondria, positively-expressing UCP-1, with a central nucleus $(2,17,20,21)$. Classical white adipocytes present a single large fat droplet and fewer mitochondria which points to its storage function (21).

Although the total mass of brown adipose tissue in mammals is small, past research has already demonstrated that its activation could quadruple the energy expenditure (EE) of an animal, as an increase in tissue perfusion occurs (15,21-23). Not only the fat stored in its lipid droplets are used to generate heat, but also free fatty acids and glucose from systemic circulation, exponentially increasing its thermogenic capacity (15). This is of particular importance to hibernating animals, as there is an urgent need to increase body temperature after microarousals which occur during hibernation $(2,21,22)$. During hibernation, its metabolism presents under hypothermia and it must achieve thermoregulation as quick as possible during microarousals or after the end of the hibernation period $(2,21)$. Only a highcapacity thermogenic tissue would be able to achieve adequate short term thermoregulation (24).
In addition to hibernators, the importance of brown adipose tissue to small mammals, which have a greater body surface area in proportion to their internal volume, is well recognized $(2,24,25)$. This greater area increases heat loss to the environment and costs more energy, used by brown adipose tissue, to maintain thermoregulation. Human newborns possess a high area/volume ratio, and it has long been documented that brown adipose tissue is present in our early life $(2,23,26-28)$. However, with the progressive reduction of surface area in relation to internal volume, the energy cost of thermoregulation is decreased and it was believed that brown adipose tissue suffered progressive involution until its total disappearance during early childhood (23). The invention and then popularization of PET-FDG changed this view however, as it was hypothesized that at least a fraction of humans still present brown adipose tissue in adult life, as the detection, in a fraction of exams, of areas of metabolic activity raised the possibility of there being unnoticed thermogenic fat $(15,23,29)$.

\section{PET-FDG: the "denouncer" of brown adipose tissue}

PET-FDG is a functional exam characterized by its ability to detect metabolically active areas that uptake FDG, a glucose radioisotope $(23,30,31)$. It began being used in the 90s, mainly in oncology, to detect tumors and metastases, which generally have a high metabolic rate and therefore high glucose uptake. The heart and brain are also consistently detected in a PET-FDG scan, organs with long recognized marked glucose utilization, even during fasting (31). Unexpectedly, however, a small fraction of PET exams detected bilateral symmetrical FDG uptake areas in supraclavicular, cervical and parasternal regions that could not easily be interpreted as tumors, due to the described characteristics $(7,29,30,32)$. Anatomically, the highly active areas were within areas of fat attenuation on computerized tomography, suggesting metabolically active fat. The high proportion of images with such characteristics on PET-FDG of pheochromocytoma diagnosed individuals, with catecholamine-producing tumors known to be of intense noradrenergic activation, raised suspicions that these areas were actually unrecognized brown adipose tissue, which had proliferated under chronic noradrenergic stimuli $(7,29,33,34)$.

The interest from endocrinologists and metabolism experts rose in 2007 after the publication of an article which showed compelling evidence, from a functional 
point of view, that these mysterious areas detected by PET-FDG scans were brown adipose tissue (29). However, just two years later, with the publication of three articles in the same edition of the New England Journal of Medicine, the scientific community accepted that at least a fraction of human adults possess brown adipose tissue $(12,13,14,35)$. We will review those articles shortly (Table 1$)$.

Cypess and cols. analyzed 3640 PET-FDGs taken to detect neoplasms and detected uptake areas suggestive of BAT in $7.5 \%$ of women and $3.1 \%$ of men (12). Age, body mass index (in older subjects), outdoor temperature and fasting glucose were inversely related to PET positive imaging, and the use of beta-blockers was associated with a lower probability of uptake. However, after multivariate analysis, fasting glucose and BMI lost their statistical significance, but BMI continued to have a significant negative relationship with uptake in older individuals.

Van Marken Lichtenbelt and cols., concomitantly, opted to perform PET-FDGs in 24 individuals after acute cold exposure (16 degrees Celsius for two hours),

Table 1. Summary of findings of the three New England Journal of Medicine articles from 2009 that confirmed to scientific community the presence of brown adipose tissue in adult humans

\begin{tabular}{|c|c|c|}
\hline $\begin{array}{l}\text { Van Marken } \\
\text { Lichtenbelt } \\
\text { and cols. (13) }\end{array}$ & $\begin{array}{c}\text { Virtanen } \\
\text { and cols. (14) }\end{array}$ & $\begin{array}{c}\text { Cypess } \\
\text { and cols. (12) }\end{array}$ \\
\hline $\begin{array}{l}\text { BAT prevalence on } \\
\text { FDG-PET in } 96 \% \text { of } \\
\text { individuals after acute } \\
\text { cold exposure }\end{array}$ & $\begin{array}{l}\text { Cold induced PET-FDG } \\
\text { uptake was } 15 \text { times } \\
\text { greater in paracervical } \\
\text { and supraclavicular } \\
\text { adipose tissue in five } \\
\text { subjects }\end{array}$ & $\begin{array}{l}\text { Positive scans seen in } \\
7.5 \% \text { of women and } \\
3.1 \% \text { of men }\end{array}$ \\
\hline $\begin{array}{l}\text { Significantly lower } \\
\text { activity in overweight } \\
\text { and obese individuals } \\
\text { (the only PET negative } \\
\text { subject was obese) }\end{array}$ & $\begin{array}{l}\text { Mathematical analysis } \\
\text { from one subject } \\
\text { suggests a } 4.1 \mathrm{~kg} \\
\text { decrease in body } \\
\text { weight over the course } \\
\text { of } 1 \text {-year if BAT is } \\
\text { active }\end{array}$ & $\begin{array}{c}\text { Probability of detection } \\
\text { inversely related to } \\
\text { outdoor temperature, } \\
\text { years of age, BMI in } \\
\text { older adults and beta } \\
\text { blocker use }\end{array}$ \\
\hline $\begin{array}{l}\text { Higher activity has a } \\
\text { significant direct } \\
\text { positive correlation with } \\
\text { resting metabolic rate } \\
\text { and correlates } \\
\text { negatively with BMI and } \\
\text { body fat mass }\end{array}$ & $\begin{array}{l}\text { Biopsy specimens of } \\
\text { three subjects were } \\
\text { collected and } \\
\text { demonstrated } \\
\text { messenger RNA and } \\
\text { protein levels of UCP-1, } \\
\text { as well as other brown } \\
\text { fat markers (such as } \\
\text { PGC1 } \alpha \text {, DI02, PRDM16 } \\
\text { and ADRB3) and } \\
\text { morphologic } \\
\text { assessment found } \\
\text { evidence of multilocular } \\
\text { fat cells }\end{array}$ & $\begin{array}{l}\text { Probability of detection } \\
\text { inversely related to } \\
\text { fasting glycemia in } \\
\text { univariate analysis, but } \\
\text { not significant in } \\
\text { multivariate analysis }\end{array}$ \\
\hline
\end{tabular}

using light clothes and avoiding shivering (13). The authors observed $96 \%$ of positive images and also demonstrated an inverse relationship between the level of uptake measured in kilobecquerels and BMI or body fat mass. The single individual that presented negative uptake after cold exposure was obese. Tissues obtained from positive uptake regions expressed UCP-1.

The last paper in the aforementioned edition of the New England Journal, by Virtanen and cols., analyzed tissue biopsy from PET positive areas visualized in three young individuals and detected positive expression of UCP-1, confirming it as being brown adipose tissue (14). Considering that only $10 \%$ of energy utilization by BAT is from glucose and $90 \%$ from fatty acids, the Finnish group calculated by mathematical analysis based on FDG uptake in these individuals, a 7\% increase in energy expenditure, which corresponds to 4.1 kilograms a year.

Neither of the studies was designed to assess causaleffect relations between BMI and the presence or absence of BAT, leading to innumerous hypotheses. One hypothesis being that as obese people have greater fat protection they may feel less cold, in turn meaning they need less BAT activation. Another possibility, which should be investigated further, is that the absence of brown adipose tissue could be, at least partially, related to weight gain and worsening of blood glucose levels in a subgroup of individuals.

\section{Is brown adipose tissue metabolically important in humans?}

For such a fascinating hypothesis to be plausible, brown adipose tissue would have to be metabolically important in humans. What evidence exists to support this?

Initially, after first PET-FDG imaging, it was hypothesized that brown adipose tissue was a residual organ, similar to other organs that frequently do not involute during embryology and development. Data from the Van Marken Lichtenbelt study demonstrated nearly $100 \%$ captation with cold stimulation and turned out this hypothesis less probable (13).

The total brown adipose tissue mass in humans is no larger than 60 to 100 grams, a minute fraction of white adipose tissue mass, even in lean individuals (23). However, as already pointed out, the perfusion of BAT increases substantially during noradrenergic stimulation, leading to a high peripheral uptake of glucose and fatty acids, which makes BAT an energy demanding tissue as well as also being an important regulator of 
glucose homeostasis $(2,22,23,35,36)$. It has an insulin independent glucose uptake capacity and helps the clearance of free fatty acids, which are closely related to insulin resistance $(35,36)$.

Some studies have tried to evaluate the energy expenditure increase after BAT activation, and variances between 5 and $77 \%$ over basal levels have been reported (23). As previously described, Virtanen and cols. suggested a $7 \%$ increase in basal metabolism (14). Orava and cols. found a similar $8 \%$ increase after cold exposure, but when the analysis was done only in PET-FDG positive individuals, the increase climbed to $22 \%$ (35). Ouellet and cols. opted to measure energy expenditure by indirect calorimetry, before and after cold exposure in an $18^{\circ} \mathrm{C}$ water filled shirt (37). The percentage increase in this study reached $77 \%$ after cold exposure. Yoneshiro and cols., divided PET-FDG positive and negative in regard to BAT activation, and found a stimulated 25\% increase in energy expenditure in the positive group, corresponding to $358 \mathrm{kcal}$ (38). The adipostat hypothesis, however, teaches us that an energy expenditure increase should necessarily lead to a parallel increase in energy intake to avoid weight variations $(39,40)$. To better understand what happens to energy balance in a situation of increased energy expenditure due to thermogenesis, animal studies should be evaluated, as very little data on humans is available.

Cannon and Nedergaard demonstrated, several years ago, increased vO2 and energy intake in animals exposed to lower temperatures; but, although the feeding increase was proportional to $\mathrm{O} 2$ consumption, the cold living animals are lighter than their counterparts (39). However, several authors, based on different results in different experiments, still believe that any increase in energy expenditure will be readily compensated by increased food intake, and that isolated BAT activation will not result in weight loss $(17,25,41,42)$. Ravussin and cols. elegantly suggested that BAT activation combined with an anorexic drug could induce weight loss synergy by dissociating the increased energy expenditure with that of food intake, but the results of his studies combining acute intermittent cold exposure with AM251, an endocannabinoid receptor antagonist, did not show any synergy nor weight loss in the group exposed to cold that did not receive the substance (42).

Yoneshiro and cols, who analyzed differences between BAT-positive and BAT-negative individuals based on their FDG-PET uptake, reported that BATpositive subjects did not gain weight with age (43).
On the other hand, BAT-negative subjects, as is common in humans, had increased BMI, total body fat mass and abdominal fat mass, supporting the notion that brown adipose tissue helps protect against weight gain and the development of obesity.

Gadea and cols. recently reported a case of a rare brown adipose tissue tumor, called hibernoma, in a 68 -year old woman who had lost $10 \mathrm{~kg}$ in 6 months (44). She gained $15 \mathrm{~kg}$ in one-year after surgery, but a decrease in energy expenditure was intriguingly not reported after resection and an increase in food intake was observed. The description of this case suggests, although obviously with all the limitations of evaluating a single case, that brown adipose tissue is capable of inducing weight loss, at least when highly present and stimulated. Another situation that deserves a mention is hyperthyroidism. Although a comprehensive review about the relation of brown adipose tissue and thyroid hormones is beyond the scope of this review, Lahesmaa and cols. have shown that overt hyperthyroidism, which frequently leads to significant weight loss, is associated with a threefold greater BAT glucose uptake, with increased energy expenditure and greater use of lipids as an energy substrate (45). The relationship between brown adipose tissue and thyroid hormones is, however, known for decades (2,46-50).

The real significance of brown adipose tissue depots in human metabolism, as seen, is still highly speculative. An old concept, resurrected by studies on brown adipose tissue that could also have an important impact on energy balance, is diet-induced thermogenesis, which will be reviewed in the next section.

\section{Diet-induced thermogenesis and metabolic inefficiency}

The components of daily energy expenditure are basal metabolic rate, the energy cost of physical activity and the thermic effect of food (51). Food thermogenesis is classically considered as the energy cost of digestion and calorie storage. Another concept however, of diet-induced thermogenesis related to energy wasting was hypothesized decades ago, with a close relation to brown adipose tissue, although it was poorly accepted and few studies have tried going down this path until recently $(17,19)$.

In 1979 Rothwell and Stock demonstrated, in a seminal study published in Nature which today has more than 1,000 citations, that in rats chronically fed with a "cafeteria-diet" consisting of a high energy value diet, 
rich in fat and carbohydrates and protein-poor, there was a disproportional increase in energy expenditure that could not be attributed to the energy cost of food alone (19). The rats gained less weight than predicted, and it was suggested that they wasted part of the ingested energy in the form of heat. In accordance with these findings, the rats had higher rectal and interscapular temperatures in the postprandial period. After sacrifice, tissue analysis confirmed a $260 \%$ increase in brown adipose tissue mass compared with control rats fed with a standard chow, suggesting that the dissipated energy derived from brown adipose tissue recruitment and activation.

Despite the impact of the study, diet-induced thermogenesis was almost forgotten, at least by human physiologists. However, in 1999, Stock himself compiled a series of overfeeding studies in humans which intended to evaluate interindividual responses to weight gain based on possible differences between fat mass and fat free mass percentages (52). Using the law of thermodynamics Stock calculated that between 30 and $45 \mathrm{~kJ} / \mathrm{kg}$ should be required to cause a one kilogram increase in body weight. However, some individuals presented values as high as $100 \mathrm{~kJ} / \mathrm{kg}$ to gain one kilogram. The only possibility, according to the author, is that this large variation is due to metabolic inefficiency and thermogenesis. Recently, Wijers and cols. found an individual linear correlation between the energy cost of a $1 \mathrm{~kg}$ weight gain and the cold-induced energy expenditure, suggesting that the same mechanism which leads to metabolic inefficiency is involved in cold-induced thermogenesis, probably brown adipose tissue (53).

A recent study, assessing post-prandial PET-FDG, with all the interpretation caveats that it causes due to post-prandial muscle glucose uptake, suggested that compared with thermoneutrality, there is BAT glucose uptake after a hypercaloric and hyperproteic diet, similar to that which occurs after cold activation (54). Nevertheless, another recent study questioned the significance of diet-induced thermogenesis, after demonstrating that chronically overfed individuals (200\% overfeeding) did not increase their BAT glucose uptake when PET-FDG scans done before and after the overfeeding period were compared (55). The postoverfeeding PET-FDG was performed four hours after the meal using a low carbohydrate diet. Timing and composition of the diet may have obscured the results.

Interestingly, the finding that individuals with constitutional thinness (CT), even at thermoneutral condi- tions, had a 16.7 times greater glucose uptake in BAT compared with normal weight control individuals (56) deserves mentioning. In contrast, women with anorexia nervosa, with a similar weight to CT individuals, had almost zero BAT glucose uptake, suggesting BAT has a role in metabolic inefficiency in this uncommon but fascinating subgroup of people.

Although it might be difficult to imagine an evolutionary advantage of metabolic inefficiency, as it is commonly accepted that obesity is the result of a thrifty phenotype adapted to store energy in a food scarce environment, a possible explanation would be that it is active in low protein diets and thermogenesis would be important to keep the animal constantly seeking protein sources $(2,17,52)$. In fact, it has been demonstrated in humans that low protein diets are associated with greater metabolic inefficiency, as well as high-protein diets leading to high thermogenesis, the latter mainly due to the high cost of digestion, metabolization and storage of this macronutrient (52,57-59).

In spite of being a highly controversial concept, and highly refuted by some $(60,61)$, the concept that brown adipose tissue may dissipate excess calories as heat and make weight gain difficult in some individuals deserves further investigation and could lead to the possible discovery of drugs which activate these mechanisms. Another debate which remains open for discussion is why some individuals would have more or less BAT than their counterparts.

\section{What is the real prevalence of brown adipose tissue? Concepts of recruitment and activation}

As highlighted previously, in 2009 Cypess and cols. found $7.5 \%$ of women and $3.1 \%$ of men to be BATpositive in ambient temperatures (12). Similar results were found in previous studies done under similar conditions, with small variations (23). After acute cold exposure, van Marken Lichtenbelt and cols., in the Netherlands, encountered $96 \%$ of BAT-positive individuals (only one obese man was BAT-negative) (13), however this number dropped to $40 \%$ in a Japanese population (38). In Brazil, there are no published studies on this subject, but unpublished data suggests even lower levels. Table 2 highlights differences in BAT uptake in different populations, in ambient temperature and after cold exposure $(12,13,14,23,30,38,62-67)$ What could the reason be for such differences considering similar protocols? 
Table 2. Prevalence of positive PET-FDG uptake in different populations from different countries

\begin{tabular}{lc}
\hline Ambient temperature & Acute cold exposure \\
\hline $\begin{array}{l}\text { USA (Cohade, and cols.) }-13.7 \% \\
\text { (winter), 4.1\% (rest of the year) }\end{array}$ & $\begin{array}{c}\text { Netherlands (von Marken Lichtenbelt, } \\
\text { and cols.) }-97 \%\end{array}$ \\
$\begin{array}{l}\text { USA (Yeung, and cols.) }-3.7 \% \\
\text { (neck fat) }\end{array}$ & Finland (Virtanen, and cols.) $-100 \%$ \\
USA (Cypess, and cols.) $-7.5 \%$ & Japan (Saito, and cols.) - 53\% (young \\
(women), 3.1\% (men) & individuals) \\
UK (Au-Yong, and cols.) $-7.2 \%$ & Japan (Yoneshiro, and cols.) $-46 \%$ \\
(winter), 2.5\% (summer) & \\
Canada (Ouellet, and cols.) $-6.8 \%$ & \\
Australia (Lee, and cols.) $-8.5 \%$ & \\
Germany (Stefan, and cols.) - 3.05\% & \\
\hline
\end{tabular}

To better understand this difference, we should return to physiology and studies in mice. If an animal lives under total thermoneutrality and is acutely exposed to cold, its first response is to shiver to protect internal temperature $(2,68)$. At that moment the animal does not possess brown adipose tissue ready to be activated and defend its temperature. As cold exposure is maintained, the animal starts to recruit BAT and activate it, decreasing shivering (although muscular resistance also improves to allow muscles to shiver without fatigue). As recruitment reaches its maximum, the animal stops shivering and all heat production comes from BAT and its UCP-1 mitochondrial uncoupling. After returning to thermoneutrality, the animal retains its recruited BAT, inactive, but ready to be activated in case of a new cold exposure. This is demonstrated by injecting norepinephrine before and after recruitment. The energy expenditure increase after recruitment is substantial, proving that BAT was recruited, ready to become active, different to what occurs before when there is no BAT recruited to be rapidly activated after acute norepinephrine stimulus (2,69-72).

This is a fundamental concept because it helps to explain why there is such a population variance in PETFDG uptake - daily chronic cold exposure probably recruits BAT, which can become more active after an acute reduction in ambient temperature. This hypothesis was confirmed by two groups that found greater BAT activation after chronic and daily cold exposure, as well as an increase in energy expenditure during acute cold exposure after chronic stimulation versus acute cold exposure in the beginning of the experiment $(73,74)$.

A higher percentage of individuals, as we might expect based on this hypothesis, present BAT-positive
PET-FDG in winter $(62,63,67)$, even when ambient temperature is controlled (63). Another fascinating theory that helps to explain this difference is that photoperiod could also interfere with BAT recruitment (63). As the days start to get shorter, in anticipation of winter, BAT may slowly be recruited, in order to have sufficient levels ready for when the cold starts, and preventing body thermoneutrality from being reliant upon shivering. Melatonin is a possible player in this process, as previous studies in hibernators generally demonstrate higher BAT mass in melatonin supplemented animals (75) and, in a recent study, a higher body temperature measured by infrared thermography (which will be discussed further) was seen in mice given a melatonin rich $10 \mathrm{mg} / \mathrm{kg}$ supplement (76).

As the concept of recruitment has been explained, the next question is how this recruitment occurs.

\section{Where does BAT come from? The difference between brown and beige adipocytes}

Research on pre-adipocytes and progenitor cells suggest that BAT, as well as white adipose tissue, originates from mesoderm, but from distinct regions (7779). Classic brown adipose tissue, as it is known, has its origins from engrailed-1-expressing cells in the central dermomyotome and from myogenic factor 5 (Myf-5) positive precursors. This myf- $5+$ lineage is the same for myocytes, but different from the lineage of white adipose tissue, derived from myf5 - cells from lateral mesoderm. It was therefore believed that in order to recruit new BAT, it would be necessary to start from initial pre-adipocyte differentiation and pass through a series of steps before developing mature brown adipocytes.

This particular view has changed since the discovery that cells present in areas of WAT, after specific stimulus (such as chronic cold exposure or norepinephrine), may be able to express UCP-1, and achieve thermogenesis (79-81). Would WAT be able to transdifferentiate in BAT? These cells, apparently white while non-stimulated, were called beige or "brite" (from brown-in-white) cells and their study developed rapidly.

The first doubt, already mentioned in the last paragraph was: any white cell could, under specific stimulus, express UCP-1 or only a specific cell lineage? This question has not been clearly solved, as different groups advocate different ideas $(17,82)$, but recent evidence points more towards a specific lineage derived from myf5 - cells $(77,80,81,83,84)$. Wu and cols. observed 
a distinct gene expression between classic white adipocytes, unable to express UCP-1 after stimulus, and beige adipocytes $(81)$. This same study also suggested that almost all adult human UCP-1 positive cells derived from beige adipocytes, questioning again whether humans possesses classic brown adipose tissue at all. Controversy increases with the study by Lidell and cols., which unequivocally demonstrates classic brown adipocytes in the interscapular region of newborns (expressing a specific gene called ZICl) (85) The much smaller frequence of $\mathrm{ZICl}$ expression in other thermogenic areas (as periadrenal and supraclavicular) of newborns suggested that beige adipocytes were responsible for thermogenesis in these areas. As these articles are very recent, it is too early to draw any definitive conclusions about the real origins of all of our UCP-1 positive cells. From a clinical perspective, the main implication in differentiating both tissues would be on possible therapeutics derived from this knowledge $(23,86,87)$. While it seems too slow and energy costing to differentiate embrionary cells through mature adipocytes, beige adipocytes, already present mixed with white adipocytes, can express UCP-1 much quicker. Research on therapeutics that permit UCP-1 expression in beige cells, increasing energy expenditure, appears to be an excellent choice.

\section{Is it possible to pharmacologically stimulate brown adipose tissue?}

After the great increase in BAT studies, the next step is the study of pathways and drugs that could lead to its differentiation, proliferation and activation, as already mentioned. A complete review of therapeutic possibilities is beyond the scope of this overview article and it has been well discussed by Bonet and cols. (86), and Broeders and cols., brilliantly reviews endogenous ways to stimulate brown adipose tissue (88). The pharmacological stimulation of brown adipose tissue will be a potential target for weight loss drugs, or as proposed by some authors, for weight maintenance drugs after weight loss $(17,86,88)$. As the potential to increase energy expenditure could be limited to achieve great weight loss in short-term, it could, on the other hand, mitigate or totally counteract the physiological decrease in energy expenditure that follows weight loss (17).

Two possibilities, linked with distinct pathways more than any drug in particular, will be briefly discussed. The first is capsaicin, which has already been studied in humans, by a Japanese group. In a series of studies Yoneshiro and cols. found that capsaicin is able to activate previously recruited BAT (89). This group drew such a conclusion by observing that energy expenditure increased after the ingestion of capsaicin in the group that had previously presented a positive PET-FDG glucose uptake. In the PET-FDG negative group, this was not observed. In another study, the same group recruited BAT after two weeks of chronic daily cold exposure in PET-FDG negative individuals (PET-FDG done under acute cold exposure) and they observed an increase in energy expenditure after the cold habituation compared with basal state (74). As a conclusion, capsaicin seems to be able to activate an already recruited brown (or beige) adipocyte.

More useful, however, would be finding drugs able of "browning" apparent white adipocytes. A much celebrated discovery, the hormone irisin, may be able to do that physiologically (90). Discovered by Bruce Spiegelman's group, this hormone is produced by skeletal muscle after FNDC5 protein cleavage, in response to physical activity and its main function would be exactly the browning of apparent white cells, being partially responsible for the positive metabolic effects of exercise. The hormone was isolated in mice but the same group also detected circulating levels of this hormone in humans. A great debate is ongoing, after some previous findings questioned the relevance of the hormone $(91,92)$. Raschke suggested that humans are unable to cleave FDNC5 and the detected irisin may just be laboratory interferences and even exogenous irisin administration in human cells does not appear to have the expected result. Independently of the future relevance of irisin in humans, "browning" drugs appear as potential therapeutic targets (86). As irisin is an endogenous substance, finding other potential endogenous browning hormones or substances seems like an excellent option, as recently reviewed (87). Our group started to evaluate BAT recruitment with circadian rhythms, believing in the possible role of melatonin, as previously mentioned (75). Since hypothalamic regulation of BAT is now being clearly recognized, hypothalamic effectors, such as orexin, also appear to have therapeutic potential $(17,93)$.

Past studies with sibutramine and more recent ones with intracerebral injection of GLP-1, in animals, suggest that both drugs could activate BAT (94-96). Although this does not change clinical prescription, the 
presence or absence of BAT could be a possible explanation for the sometimes incomprehensible interindividual variability in weight loss with both sibutramine and GLP-1 agonists $(97,98)$.

\section{Does brown adipose tissue play a role in diabetes, independently of weight loss?}

Various physiological mechanisms previously described support the hypothesis that BAT regulates glucose homeostasis. Examples are the increased energy expenditure and possible weight loss seen in animal models and an increase in the uptake of free fatty acids (a major player in insulin resistance) as well as the uptake of insulin independent glucose when there is greater BAT perfusion (99). Clinical data supports this theory as BAT uptake is inversely related to fasting blood glucose levels, as already mentioned.

A recent review explores these possible mechanisms to exhaustion and suggests different ones, such as $b a$ tokines, substances produced by BAT, like BMP8B, FGF21 and PTGDS, which can be implicated in improving insulin sensitivity and even insulin secretion by pancreatic beta-cells (99).

There are some studies with brown adipose tissue transplantation which demonstrate improvement in glucose homeostasis. Stanford and cols. transplanted BAT from male donor mice into the visceral cavity of age and sex matched recipient mice and found improved glucose tolerance and insulin sensitivity as well as a complete reversal of high-fat induced insulin resistance (100). Gunawardana and cols. studied mice with streptozocin induced diabetes, a model of type 1 diabetes, which also presented a significant improvement in glycemic response after BAT transplantation, supporting an insulin independent effect (101).

Therefore, evidence linking brown adipose tissue (or a lack of) with type 2 diabetes is emerging and should be an important field of research over the next few years.

\section{New imaging methods for the detection of brown adipose tissue}

The difficulties of studying BAT derive in part from the detection methods. PET-FDG was fundamental to the identification of BAT in human adults, but it is an expensive method, involving ionizing radiation, and depends on activation to be detected (17). As only $10 \%$ of BAT uptake comes from glucose, the sensitivity of a mainly glucose uptake method can be low (15).
New imaging methods are therefore being proposed to substitute PET-FDG in research and even clinical practice (102). Validation studies of magnetic resonance have already been done in animals, with promising results and good capacity for detecting brown depots within white adipose tissue (103-106). Pilot studies have also been performed in humans and suggest a good sensitivity with the additional advantage of detecting even non active tissue (although, logically, it must have at least been recruited) $(106,107)$.

Another viable option is infrared thermography (IT), a non-invasive and simple method, which evaluates body temperature in different tissues by image (a method long used in civil construction and in medical conditions such as pain and cancer $)(108,109)$. The feasibility of obtaining results with IT makes it a promising and useful method, as demonstrated by a letter from Lee and Ho, which describes an increase in temperature in BAT correspondent areas after cold exposure and meals in humans (110). Studies in children with infrared thermography have also found promising results (111).

Dual energy computerized tomography (DECT) appears to be a new option, as recently reviewed by Borga and cols (102).

In conclusion, the study of brown adipose tissue grew enormously after human adult detection by FDGPET, becoming an intense research field not only in general biology but also in medicine. Most are recent discoveries and therefore need further confirmation and validation, but there is already a vast amount of data that puts BAT as an emerging protagonist in the fields of obesity and diabetes.

A better understanding of the differences between classic brown and beige adipocytes, and between recruitment and activation, may lead to a great impulse in the development of diabetes and obesity drugs that act through BAT. Browning apparent white adipocytes, and making them express UCP-1 and generating heat seems easier, under specific stimulus, than differentiating new preadipocytes from classic brown cells.

The idea that part of interindividual weight gain can be explained by greater diet-induced thermogenesis, or metabolic inefficiency, is also fascinating and could help to change some obesity (and constitutional thinness) paradigms and misconceptions. Unfortunately, the vast majority of clinical practitioners still see obesity as a minor condition associated to individual choices, despite decades of obesity research pointing in a different direction. 


\section{REFERENCES}

1. Gessner K. Historiae Animalium: Lib I De Quadrupedibus viviparis. 1551.

2. Cannon B, Nedergaard J. Brown adipose tissue: function and physiological significance. Physiol Rev. 2004;84(1):277-359.

3. Tam CS, Lecoultre V, Ravussin E. Brown adipose tissue: mechanisms and potential therapeutic targets. Circulation. 2012;125(22):2782-91.

4. Himms-Hagen J. Obesity may be due to a malfunctioning of brown fat. Can Med Assco J. 1979;121:1361-4.

5. Joy RTJ. Responses of cold-acclimated men to infused norepinephrine. J Appl Physiol. 1963;18:1209-12.

6. Jung RT, Leslie P, Nicholls DG, Cunningham S, IslesTE. Energy expenditure in normal and diabetic man: the role of brown adipose tissue. Health Bull (Edinb). 1988;46(1):55-62.

7. Kang BS, Han DS, Paik KS, Park YS, Kim JK, Kim CS, et al. Calorigenic action of norepinephrine in the Korean women divers. J Appl Physiol. 1970;29:6-9.

8. Lesna I, Vybıral S, Jansky L, Zeman V. Human nonshivering thermogenesis. JTherm Biol. 1999;24:63-9.

9. Bouillaud F, Villarroya F, Hentz E, Raimbault S, Cassard AM, Ricquier $\mathrm{D}$. Detection of brown adipose tissue uncoupling protein mRNA in adult patients by a human genomic probe. Clin Sci. 1988;75:21-7.

10. Hany TF, Gharehpapagh E, Kamel FM, Buck A, Himms-Hagen J, von Schulthess GK. Brown adipose tissue: a factor to consider in symmetrical tracer uptake in the neck and upper chest region. Eur J Nucl Med Mol Imaging. 2002;29(10):1393-8.

11. Nedergaard J, Bengtsson T, Cannon B. Unexpected evidence for active brown adipose tissue in adult humans. Am J Physiol Endocrinol Metab. 2007;293:E444-52.

12. Cypess AM, Lehman S, Williams G, Tal I, Rodman D, Goldfine AB, et al. Identification and importance of brown adipose tissue in adult humans. N Engl J Med. 2009;360(15):1509-17.

13. van Marken Lichtenbelt WD, Vanhommerig JW, Smulders NM, Drossaerts JM, Kemerink GJ, Bouvy ND, et al. Cold-activated brown adipose tissue in healthy men. N Engl J Med. 2009;360 (15):1500-8.

14. Virtanen KA, Lidell ME, Orava J, Heglind M, Westergren R, Niemi $\mathrm{T}$, et al. Functional brown adipose tissue in healthy adults. $\mathrm{N}$ Engl J Med. 2009;360(15):1500-8.

15. Nedergaard J, Bengtsson T, Cannon B. Three years with adult human brown adipose tissue. Ann NY Acad Sci. 2010;1212:E20-36.

16. Matthias A, Ohlson KB, Fredriksson JM, Jacobsson A, Nedergaard J, Cannon B. Thermogenic responses in brown cells are fully UCP1-dependent. UCP2 or UCP3 do not substitute for UCP1 in adrenergically or fatty-acid indeuced thermogenesis. $\mathrm{J}$ Biol Chem. 2000;275:25073-81.

17. Chechi K, Nedergaard J, Richard D. Brown adipose tissue as an anti-obesity tissue in humans. Obes Rev. 2014;15:92-106.

18. Arch JAT, Ainsworth AT, Cawthorne MA, Piercy V, Sennitt MV, Thody VE, et al. Atypical beta-adrenoceptor on brown adipocytes as target for anti-obesity drugs. Nature. 1984;309:163-5.

19. Rothwell NJ, Stock MJ. A role for brown adipose tissue in dietinduced thermogenesis. Nature. 1979;281(5726):31-5.

20. Cinti S. The adipose organ at a glance. Dis Model Mech. 2012;5(5):588-94.

21. Smith RE, Hock RJ. Brown fat: thermogenic effector of arousal in hibernators. Science. 1963;140:199-200.

22. Smith RE. Thermoregulatory and adaptive behavior of brown adipose tissue. Science. 1964;146:1686-9.

23. Lee $P$, Swarbrick MM, Ho KK. Brown adipose tissue in adult humans: a metabolic renaissance. Endocr Rev. 2013;34(3):413-38.
24. Silva JE. Thermogenic mechanisms and their hormonal regulation. Physiol Rev. 2006;86(2):435-64.

25. Ravussin E, Galgani JE. The implication of brown adipose tissue for humans. Ann Rev Nutr. 2011;31:33-47.

26. Hatai S. On the presence in human embryos of an interscapular gland corresponding to the so-called hibernating gland of lower mammals. Anat Anz. 1902;21:369-73.

27. Rasmussen $A$. The glandular status of brown multilocular adipose tissue. Endocrinology. 1922;6:760-70.

28. Dawkins MJ, Scopes JW. Non-shivering thermogenesis and brown adipose tissue in the human new-born infant. Nature. 1965;206:201-2.

29. Nedergaard J, Bengtsson T, Cannon B. Unexpected evidence for active brown adipose tissue in adult humans. Am J Physiol Endocrinol Metab. 2007;293:E444-52.

30. Yeung HWD, Grewal RK, Gonen M, Schöder H, Larson SM. Patterns of 18F-FDG uptake in adipose tissue and muscle: a potential source of false-positives for PET. J Nucl Med. 2003;44:1789-96.

31. Hironaka FH, Sapienza MT, Ono CR, Lima MS, Buchpiguel CA. Base do estudo PET com FDG. In: Medicina Nuclear: Princípios e Aplicações. Ed Atheneu. 2012;15;332-5.

32. Barrington SF, Maisey MN. Skeletal muscle uptake of fluorine18-FDG: effect of oral diazepam. J Nucl Med. 1996;37:1127-9.

33. Lean ME, JamesWP, Jennings G, Trayhurn P. Brown adipose tissue in patients with phaeochromocytoma. Int J Obes. 1986;10:219-27.

34. Hadi M, Chen CC, Whatley M, Pacak K, Carrasquillo J. Brown fat imaging with 18F-6-Fluorodopamine PET/CT, 18F-FDG PET/CT, and 123I-MIBG SPECT: a study of patients being evaluated for pheochromocytoma. J Nucl Med. 2007;48:1077-83.

35. Orava J, Nuutila P, Lidell ME, Oikonen V, Noponen T, Viljanen T, et al. Different metabolic responses of human brown adipose tissue to activation by cold and insulin. Cell Metab. 2011;14:272-9.

36. Peirce V, Vidal-Puig A. Regulation of glucose homeostasis by brown adipose tissue. Lancet. 2013;1(4):353-60.

37. Ouellet $\mathrm{V}$, Labbe SM, Blondin DP, Phoenix S, Guérin B, Haman F, et al. Brown adipose tissue oxidative metabolism contributes to energy expenditure during acute cold exposure in humans. J Clin Invest. 2012;122:545-52.

38. Yoneshiro T, Aita S, Matsushita M, Kameya T, Nakada K, Kwai Y, et al. Brown adipose tissue, whole body energy expenditure and thermogenesis in healthy adult men. Obesity (Silver Spring). 2011;19:1755-60.

39. Cannon B, Nedergaard J. Thermogenesis challenges the adipostat hypothesis for body weight control. Proc Nutr Soc. 2009;68(4):401-7.

40. Kennedy GC. The role of depot fat in the hypothalamic control of food intake in the rat. Proc Royal Soc Lond B Biol. Sci. 1953;140:578-92.

41. Barnett SA. Adaptation of mice to cold. Biol Rev Camb Philos Soc. 1965;40:5-51.

42. Ravussin Y, Xiao C, Gavrilova O, Reitman ML. Effect of intermittent cold exposure on brown fat activation, obesity and energy homeostasis in mice. PLoS ONE. 2014;9(1):e85876.

43. Yoneshiro T, Aita S, Matsushita M, Okamatsu-Ogura $Y$, Kameya $T$, Kawai $Y$, et al. Age-related decrease in cod-activated brown adipose tissue and accumulation of body fat in healthy humans. Obesity. 2011;19:1755-60.

44. Gadea E, Thivat E, Paulon R, Mishellany F, Gimbergues P, Capel F, et al. Hibernoma: a clinical model for exploring the role of brown adipose tissue in the regulation of body weight? J Clin Endocrol Metab. 2014;99(1):1-6.

45. Lahesmaa M, Orava J, Schalin-Jäntii C, SOinio M, Hannukainen JC, Noponen T, et al. Hyperthyroidism increases brown fat metabolism in humans. J Clin Endocr Metab. 2014;99(1):E28-35. 
46. Branco M, Ribeiro M, Negrao N, Bianco AC. 3,5,3'-Triiodothyronine actively stimulates UCP in brown fat under minimal sympathetic activity. Am J Physiol Endocrinol Metab. 1999;276: E179-87.

47. Bianco AC, Sheng X, Silva JE. Triiodothyronine amplifies norepinephrine stimulation of uncoupling protein gene transcription by a mechanism not requiring protein synthesis. J Biol Chem. 1988;263:18168-75.

48. Ilye's I, Stock MJ. Effects of hypothyroidism and hyperthyroidism on thermogenic responses to selective and nonselective betaadrenergic agonists in rats. Acta Med Hung. 1990;47:179-88.

49. Rothwell NJ, Stock MJ, Sudera DK. Changes in adrenoreceptor density in brown adipose tissue from hyperthyroid rats. Eur $\mathrm{J}$ Pharmacol. 1985;114:227-9.

50. Sundin U, Mills I, Fain JN. Thyroid-catecholamine interactions in isolated rat brown adipocytes. Metabolism. 1984;33:1028-33.

51. Ravussin E, Lillioja S, Anderson TE, Christin L, Bogardus C. Determinants of 24-hour energy expenditure in man. Methods and results using a respiratory chamber. J Clin Invest. 1986;78:1568-78.

52. Stock MJ. Gluttony and thermogenesis revisited. Int $\mathrm{J}$ Obes. 1999;23:1105-17.

53. Wijers SLJ, Saris WHM, Wouter D. Individual thermogenic responses to mild cold and overfeeding are closely related. J Clin Endocrinol Metab. 2007;92(11):4299-305.

54. Vosselman MJ, Brans B, van der Lans AA, Wierts $R$, van Baak MA, Mottaghy FM, et al. Brown adipose tissue after a high-calorie meal in humans. Am J Clin Nutr. 2013;98:57-64.

55. Schlögl M, Piaggi P, Thiyyagura P, Reiman EM, Chen K, Lutrin C, et al. Overfeeding over 24 hours does not activate brown adipose tissue in humans. J Cin Endocrinol Metab. 2013;98(12):E1956-60.

56. Pasanisi F, Pace L, Fonti R, Marra M, Sgambati D, De Caprio C, et al. Evidence of brown fat activity in constitutional leanness. J Clin Endocrinol Metab. 2013;98(3):1214-8.

57. Hamilton JS. Heat increments of diets balanced and unbalanced with respect to protein. J Nutr. 1939;17:583-99.

58. Miller DS, Payne PR. Weight-maintenance and food intake. J Nutr. 1962;78:255-62.

59. Rothwell NJ, Stock MJ, Tyzbir RS. Energy balance and mitochondrial function in liver and brown fat of rats fed 'cafeteria' diets of varying protein content. J Nutr. 1982;112:1663-72.

60. Maxwell GM, Nobbs S, Bates DJ. Diet-induced thermogenesis in cafeteria-fed rats: a myth? Am J Physiol. 1987;253:E264-70.

61. Kozak LP. Brown fat and the myth of diet-induced thermogenesis. Cell Metab. 2010;11:263-7.

62. Cohade C, Osman M, Pannu HK, Wahl RL. Uptake in supraclavicular area fat ("USA-Fat"): description on 18FFDG-PET/CT. J Nucl Med. 2003;44:170-6.

63. Au-Yong IT, Thorn N, Ganatra R, Perkins AC, Symonds ME. Brown adipose tissue and seasonal variation in humans. Diabetes. 2009;58:2583-7.

64. Ouellet V, Routhier-Labadie A, Bellemare W, Lakhal-Chaieb L, Turcotte $\mathrm{E}$, Carpentier AC, et al. Outdoor temperature, age, sex, body mass index, and diabetic status determine the prevalence, mass, and glucose-uptake activity of 18F-FDG-detected BAT in humans. J Clin Endocrinol Metab. 2011;96:192-9.

65. Lee P, Ho KK, Fulham MJ. The importance of brown adipose tissue. N Engl J Med. 2009;361:418; author reply, 419-20.

66. Stefan N, Pfannenberg C, Haring HU. The importance of brown adipose tissue. N Engl J Med. 2009;361:416-7; author reply, 418-21.

67. Saito M, Okamatsu-Ogura Y, Matsushita M, Watanabe K, YoneshiroT, Nio-Kobayashi J, et al. High incidence of metabolically active brown adipose tissue in healthy adult humans: effects of cold exposure and adiposity. Diabetes. 2009;58:1526-31.

68. Griggio MA. The participation of shivering and nonshivering thermogenesis in warm and cold-acclimated rats. Comp Biochem Physiol A Physiol. 1982;73:481-4.
69. Soni A, Katoch SS. Structural and metabolic changes in skeletal muscle of cold acclimated rats. JTherm Biol. 1997;22:95-107.

70. Hart JS, Heroux O, Depocas F. Cold acclimation and the electromyogram of unanesthetized rats. J Appl Physiol. 1956;9:404-8.

71. Foster DO, Frydman ML. Tissue distribution of cold-induced thermogenesis in conscious warm- or cold-acclimated rats reevaluated from changes in tissue blood flow: the dominant role of brown adipose tissue in the replacement of shivering by nonshivering thermogenesis. Can J Physiol Pharmacol. 1979;57:257-79.

72. Jacobsson A, Muhleisen M, Cannon B, Nedergaard J. The uncoupling protein thermogenin during acclimation: indications for pretranslational control. Am J Physiol. 1994;267(4 Pt 2):R999-1007.

73. Anouk AJJ, Hoeks J, Brans B, Vijgen GHEJ, Visser MGW, Vosselman $\mathrm{MJ}$, et al. Cold acclimation recruits human brown fat and increases nonshivering thermogenesis. J Clin Invest. 2013;123(8):3395-403.

74. YoneshiroT, Aita S, Matsushita M, Kayahara T, Kameya T, KawayY, et al. Recruited brown adipose tissue as an antiobesity target in humans. J Clin Invest. 2013;123(8):3404-8.

75. Tan DX, Manchester LC, Fuentes-Broto L, Paredes SD, Reiter RJ. Significance and application of melatonin in the regulation of brown adipose tissue metabolism: relation to human obesity. Obes Rev. 2011;12:167-88.

76. Jimenez-Aranda A, Fernadez-Vazquez G, Campos D, Tassim M, Velasco-Perez, Tan DX, et al. Melatonin induces browning of inguinal white adipose tissue in Zucker diabetic fatty rats. J Pineal Res. 2013;55(4):416-23.

77. Enerback E. The origins of brown adipose tissue. N Engl J Med. 2009;360(19):2021-3.

78. Tang W, Zeve D, Suh JM, Bosnakovski D, Kyba M, Hammer RE, et al. White fat progenitor cells reside in the adipose vasculature. Science. 2008;322:583-6.

79. Seale P, Bjork B, Yang W, Kajimura S, Kuang S, Scime A, et al. PRDM16 controls a brown fat/skeletal muscle switch. Nature. 2008;454:961-8.

80. Xue B, Cao R, Hogan JC, Coulter AA, Koza RA, Kozak LP. Genetic variability affects the development of brown adipocytes in white fat but not in interscapular brown fat. J Lipid Res. 2007;48:41-51.

81. Wu J, Boström P, Sparks LM, Ye L, Choi JH, Giang AH, et al. Beige adipocytes are a distinct type of thermogenic fat cell in mouse and human. Cell. 2012;150:366-76.

82. Smorlesi A, Frontini A, Giordano A, Cinti S. The adipose organ: white-brown adipocyte plasticity and metabolic inflammation. Obes Rev. 2012;13(2):83-96.

83. Sharp LZ, Shinoda K, Ohno H, Scheel DW, Tomoda E, Ruiz L, et al. Human BAT possesses molecular signatures that resemble beige/brite cells. PLoS ONE. 2012;7:e49452.

84. Cannon B, Nedergaard J. Cell biology: neither brown nor white. Nature. 2012;488:286-7.

85. Lidell ME, Betz MJ, Leinhard OD, Heglind M, Elander L, Slawik M, et al. Evidence for two types of brown adipose tissue in humans. Nat Med. 2013;19(5):631-4.

86. Bonet ML, Oliver P, Palou A. Pharmacological and nutritional agents promoting browning of white adipose tissue. Biochim Biophys Acta. 2013;1831(5):969-85.

87. Lidell ME, Betz MJ, Enerbäck S. Brown adipose tissue and its therapeutical potential. J Intern Med. 2014;276(4):364-77.

88. Broeders E, Bouvy ND, van Marken Lichtenbelt WD. Endogenous ways to stimulate brown adipose tissue in humans. Ann Med. 2014 [Epub ahead of print].

89. Yoneshiro T, Aita S, KawaiY, IwanagaT, Saito M. Nonpungent capsaicin analogs (capsinoids) increase energy expenditure through the activation of brown adipose tissue in humans. Am J Clin Nutr. 2012;95(4):845-50. 
90. Bostrom P, Wu J, Jedrychowski MP, Korde A, Ye L, Lo JC, et al. A PGC1- $\alpha$-dependent myokine that drives brown-fat-like development of white fat and thermogenesis. Nature. 481:463-8.

91. Raschke S, Elsen M, Gassenhuber H, Sommerfeld M, Scwahn U, Brockmann B, et al. Evidence against a beneficial effect of irisin in humans. PLoS One. 2013;8(9):e73680.

92. Kurdiova T, Balaz M, Mayer A, Maderova D, Belan V, Wolfrum $C$, et al. Exercise-mimicking treatment fails to increase Fndc5 mRNA \& irisin secretion in primary human myotubes. Peptides. 2014;56C:1-7.

93. Sellayah D, Bharaj $P$, Sikder D. Orexin is required for brown adipose tissue development, differentiation and function. Cell Metab. 2011;14:478-90.

94. Giordano A, Centemeri C, Zingaretti MC, Cinti S. Sibutraminedependent brown fat activation in rats: an immunohistochemical study. Int J Obes Relat Metab Disord. 2002;26(3):354-60.

95. Lockie SH, Heppner KM, Chaudhary N, Chabenne JR, Morgan DA, Veyrat-Durebex $\mathrm{C}$, et al. Direct control of brown adipose tissue thermogenesis by central nervous system glucagon-like peptide receptor signaling. Diabetes. 2012;61(11):2753-62.

96. Lockie SH, Stefanidis A, Oldfield BJ, Perez-Tilve D. Brown adipose tissue thermogenesis in the resistance to and reversal of obesity: a potential new mechanism contributing to the metabolic benefits of proglucagon-derived peptides. Adipocyte. 2013;2(4):196200.

97. Arterburn DE, Crane PK, Veenstra DL. The efficacy and safety of sibutramine for weigth loss. Arch Intern Med. 2004;164(9):9941003.

98. Vilsboll T, Christensen M, Junker AE, Knopp FK, Gluud K. Effects of glucagon-like peptide-1 receptor agonists on weight loss: systematic review and meta-analyses of randomized controlled trials. BMJ. 2012;344:d7771.

99. Peirce V, Vidal-Puig A. Regulation of glucose homeostasis by brown adipose tissue. Lancet. 2013;1(4):353-60.

100. Stanford KI, Middelbeek JW, Townsend KL, An D, Nygaard EB, Hitchcox KM, et al. Brown adipose tissue regulates glucose homeostasis and insulin sensitivity. J Clin Invest. 2013;123(1): 215-23.
101. Gunawardana SC, Piston DW. Reversal of type 1 diabetes in mice by brown adipose tissue transplant. Diabetes. 2012;61(3):674-82.

102. Borga M, Virtanen KA, RomuT, Leinhard OD, Persson A, Nuutila $P$, et al. Brown adipose tissue in humans: detection and functional analysis using PET (positron emission tomography), MRI (magnetic resonance imaging), and DECT (dual energy computed tomography). Methods Enzymol. 2014;537:141-59.

103. Chen YI, Cypess AM, Sass CA, Brownell A, Jokivarsi KT, Kahn CR, et al. Anatomical and functional assessment of brown adipose tissue by magnetic resonance imaging. Obesity. 2012;20:1519-26.

104. Grimpo K, Volker MN, Heppe EN, Braun S, Heverhagen JT, Heldmaier G. Brown adipose tissue dynamics in wild-type and UC1-knockout mice: in vivo insights with magnetic resonance. $J$ Lipid Res. 2014;55(3):398-409.

105. Branca RT, Zhang L, Warren WS, Auerbach E, Khanna A, Degan $S$, et al. In vivo noninvasive detection of brown adipose tissue throughintermolecular zero-quantum MRI. PLoS. 2013;8(9):e74206.

106. Holstila M, Virtanen KA, Grönroos TJ, Laine J, Lepomäki V, Saunavaara $\mathrm{J}$, et al. Measurement of brown adipose tissue mass using a novel dual-echo magnetic resonance imaging approach: a validation study. Metabolism. 2013;62(8):1189-98.

107. Reddy NL, Jones TA, Wayte SC, Adesanya O, Sankar S, Yeo YC, et al. Identification of brown adipose tissue in a human adult with histological and immunohistochemical confirmation. J Clin Endocrinol Metab. 2014;99(1):E117-21.

108. Ramanathan NL. A new weighting system for mean surface temperature of the human body. J Appl Physiol. 1964;19:531-3.

109. Deng ZS, Liu J. Mathematical modeling of temperature mapping over skin surface and its implementation in thermal disease diagnostics. Comput Biol Med. 2004;34:495-521.

110. Lee $P$, Ho KKY. Hot fat in a cool man: infrared thermography and brown adipose tissue. Diab Obes Metab. 2011;13:92-3.

111. Symonds ME, Henderson K, Elvidge L, Bosman C, Sharkey D, Perkins $A C$, et al. Thermal imaging to assess age-related changes of skin temperature within the supraclavicular region co-locating with brown adipose tissue in healthy children. $\mathrm{J}$ Pediatr. 2012;161:892-8. 